\title{
BANKOWOŚĆ PRYWATNA - STAN I PERSPEKTYWY ROZWOJU W POLSCE
}

\section{WSTĘP}

Rosnąca zamożność polskiego społeczeństwa spowodowała, że klasyczna działalność banków komercyjnych nie zaspokaja oczekiwań najbogatszych klientów, które stają się wyznacznikiem dynamicznego rozwoju sektora bankowości detalicznej, jakim jest bankowość prywatna (private banking).

Bankowość prywatna w Polsce, mimo swojej dość krótkiej historii, rozwija się równolegle ze wzrostem zamożności Polaków i stanowi aktualnie najbardziej zaawansowaną formę polskiej bankowości detalicznej. Różni się ona co prawda od form znanych m.in. z rozwiniętych rynków - szwajcarskiego czy austriackiego, buduje jednak własną tożsamość i posiada pewne cechy, które nie tylko wyróżniają ją na tle innych usług bankowych, ale sprawiają również, że uzasadnione jest nazywanie jej nowym specjalistycznym segmentem bankowości detalicznej o wysokim potencjale rozwojowym ${ }^{1}$.

Głównym celem artykułu jest ukazanie aktualnego stanu bankowości prywatnej wraz z jej kompleksową ofertą i serwisem, plasującymi ją w czołówce najprężniej rozwijających się obszarów bankowości detalicznej. Wpływ na postać i dalsze perspektywy rozwoju polskiego private banking, poza zwiększajacymi się potrzebami i oczekiwaniami finansowymi najbogatszych klientów, ma również efekt naśladownictwa trendów panujących w bankowości krajów rozwiniętych oraz ciagłego dostosowywania do aktualnie panujących warunków makroekonomicznych, stopnia rozwoju polskiego rynku finansowego oraz stopnia zamożności i możliwości kapitałowych polskiego społeczeństwa. Podstawę uwag dotyczacych aktualnego stanu i perspektyw dalszego rozwoju segmentu private banking stanowi analiza przesłanek i założeń kształtowania przez banki relacji z najzamożniejszymi i najbardziej wymagającymi klientami.

Artykuł składa się z sześciu części. Pierwsza i druga część opracowania mają charakter wprowadzający i pozwalają poznać istotę, cele i główne klasyfikacje private banking. Część trzecia i czwarta opisują światowe wzorce bankowości prywatnej oraz główne determinanty jej rozwoju i różnice cechujące polską wersję private banking. W części piątej przedstawieni zostali główni oferenci usług bankowości prywatnej na rynku polskim.

${ }^{1}$ Zob. http://privatebanking.warszawa.pl/?m=20150225. 


\section{POJĘCIE I ISTOTA BANKOWOŚCI PRYWATNEJ}

Podstawą funkcjonowania współczesnej bankowości jest koncentracja na kliencie. Biorąc pod uwagę konieczność przestrzegania zasady efektywności działania oraz sprostania wymaganiom klientów, banki zmuszone są do odmiennego traktowania poszczególnych grup klientów. Współczesna bankowość oferuje klientom indywidualnym następujące zakresy obsługi: bankowość detaliczna (retail banking), bankowość personalna/osobista (personal banking) oraz bankowość prywatna dla najzamożniejszych klientów indywidualnych (private banking). Logiczną konsekwencją segmentacji klientów jest wprowadzenie odmiennego standardu produktów i usług finansowych oraz sposobu ich oferowania każdemu z wymienionych zakresów bankowej obsługi klienta indywidualnego ${ }^{2}$.

Kluczem służącym selekcji klientów jest przede wszystkim stopień zamożności, przy czym trudno mówić o jednym, uniwersalnie stosowanym kryterium tego podziału, dlatego instytucje bankowe rozstrzygają tę kwestię indywidualnie - co szczegółowo omówione zostało w dalszej części opracowania.

Najliczniejszą grupę wśród klientów indywidualnych stanowią osoby dysponujące aktywami finansowymi o niskiej wartości. Oferta bankowa skierowana do tej grupy klientów obejmuje podstawowy zakres produktów i usług finansowych, oferowanych w sposób masowy i wystandaryzowany. Mniej liczna grupa klientów dysponujących aktywami finansowymi o wyższej wartości wymaga bardziej indywidualnego traktowania. Oferta personal banking przeznaczona jest dla klientów średniozamożnych, dysponujących aktywami o średniej wartości, których oczekiwaniom nie odpowiada masowa bankowość detaliczna. Najmniej liczna grupa klientów indywidualnych są klienci dysponujący aktywami o najwyższej wartości, którzy w dalszej części opracowania określani są jako najzamożniejsi i dla których przewidziana i kierowana jest oferta private banking ${ }^{3}$.

Biorąc pod uwagę skalę rozpiętości standardów obsługi pomiędzy skrajnymi zakresami, tj. bankowością detaliczną i private banking, oraz różnice pomiędzy dostępnymi w nich usługami i produktami, bankowości detalicznej przypisać można nieliczne usługi dla wszystkich, natomiast ofercie private banking szeroki wachlarz produktów i usług skierowanych dla nielicznych ${ }^{4}$.

Pojęcie private banking charakteryzuje się mnogością definicji oraz trudnością w dokładnym ukazaniu jego istoty. W skrócie określa ono zindywidualizowany i kompleksowy system finansowej obsługi najzamożniejszych klientów indywidualnych ${ }^{5}$.

${ }^{2}$ L. Dziawgo, Private banking - istotny element współczesnej bankowości, „Bank i Kredyt” 2003, nr 2.

${ }^{3}$ L. Dziawgo, Private banking. Bankowość dla zamożnych klientów, Wolters Kluwer, Kraków 2006, s. 48-52.

${ }^{4}$ J. Ulrich, Private Real Estate Management im Private Banking, Uhlen Bruch Verlag, Bad Soden 2001, s. 57-59.

5 Najczęstsza definicja stosowana wśród banków kierujących ofertę dla najzamożniejszych klientów detalicznych. 
W literaturze przedmiotu private banking definiowany jest $\mathrm{w}$ ujęciu instytucjonalnym, funkcjonalnym lub łącznym, tj. instytucyjno-funkcjonalnym. W ujęciu instytucjonalnym kluczowe znaczenie ma podmiot oferujący, jakim jest instytucja bankowa; o private banking mówi się, gdy stanowi on ofertę bankowa. Ujęcie funk cjonaln e definiuje private banking jako zespół kompleksowych czynności wykorzystujących produkty i usługi skierowane do odpowiedniego klienta, bez względu na podmiot oferujący. Ujęcie instytucjonalno-funkcjonalne, jako połączenie dwóch poprzednich, zwraca uwagę zarówno na odpowiedniość czynności skierowanych do właściwego klienta, jak i na podmiot, który przygotował ofertę

Istote private banking najlepiej oddaje definicja o charakterze instytucjonalno-funkcjonalnym, zgodnie z która jest to zindywidualizowana oferta i kompleksowa obsługa przez wyspecjalizowany bank lub też wyodrębniona część banku uniwersalnego jego najzamożniejszych klientów. Definicja ta według Leszka Dziawgo ma charakter podstawowy i uniwersalny i może stanowić fundament dalszych rozważań na temat bankowości prywatnej. Główne elementy tej definicji przedstawione zostały na schemacie 1 .

\section{Schemat 1}

Podstawowe elementy definicji private banking

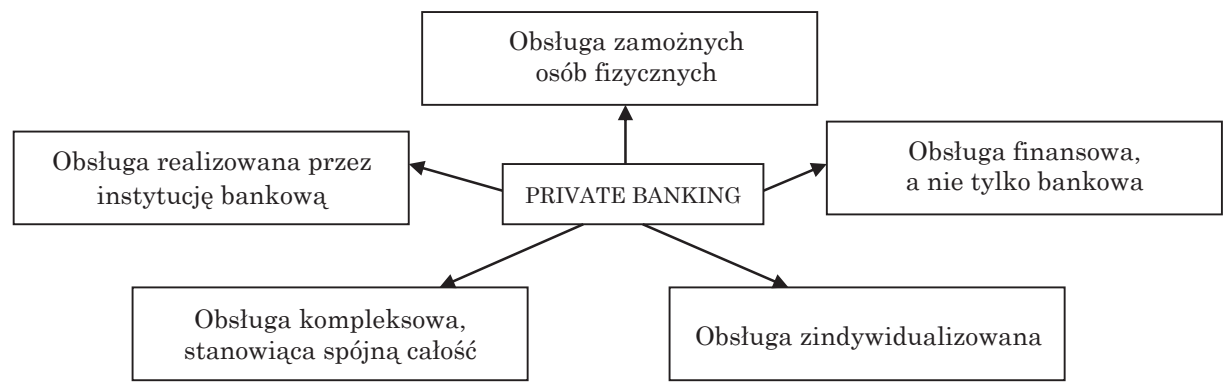

Źródło: L. Dziawgo, Private banking. Bankowość dla zamożnych klientów, Wolters Kluwer, Kraków 2006, s. 15-16.

Wielowymiarowa obsługa stanowiąca podstawę omawianej definicji rozumiana jest jako zespół określonych co do rodzaju i zakresu czynności wykorzystujących zróżnicowane i odpowiednie produkty oraz usługi. Same produkty i usługi finansowe różnią się od siebie, ale mogą być stosowane w sposób łączny ${ }^{7}$. Przyjęcie terminologii ujmujaccej produkty i usługi finansowe łącznie lepiej oddaje specyfikę funkcjonowania rynku finansowego.

Private banking obejmuje rozbudowaną ofertę produktów i usług finansowych nie tylko o charakterze ściśle bankowym ${ }^{8}$. Coraz szerszy zakres ob-

${ }^{6}$ L. Dziawgo, Private banking. Bankowość..., passim.

7 Ibidem, s. 13-20.

${ }^{8}$ L. Dziawgo, Od personal banking do private banking, w: K. Karpuś, J. Węcławski (red.), Rynek finansowy. Szanse i zagrożenia rozwoju, Wyd. UMCS, Lublin 2005, s. 77-90. 
sługi nie tylko wymuszaja wymagania klientów, ale jest on również stymulowany przez sam bank, którego celem jest zwiększenie efektywności współpracy z klientem. Oferta ta wykracza znacznie poza standardowe produkty, a jej główna cechą jest zindywidualizowanie pod względem celów i możliwości (wielkość powierzonych aktywów) danego klienta. Indywidualna obsługa $\mathrm{w}$ ramach private banking polega na kształtowaniu długoterminowej współpracy z klientem, wspartej kompleksowa, ale zarazem spójną i zintegrowana w całość, dostosowaną do potrzeb klienta oferta. Warunek kompleksowości jest tutaj wielowymiarowy, oznacza bowiem oferowanie w odpowiednim czasie i w odpowiedni sposób odpowiednio dobranego zestawu produktów i usług zaspokajających potrzeby klienta w odpowiednim horyzoncie czasowym, w całym okresie współpracy z klientem.

Samo określenie private banking ma swój polski odpowiednik: „bankowość prywatna". Budzi on pewne zastrzeżenia, dlatego że kojarzy się z forma własności kapitału w bankowości jako banków wyposażonych w kapitał prywatnych właścicieli. Na Zachodzie sprzeciw i uwagi dotyczące niepożądanej zbieżności pojęć wyrażanych jednym sformułowaniem „bankowość prywatna” zgłaszane były przez grupę prywatnych banków szwajcarskich Swiss Private Bankers Association. Nie zmienia to faktu, że zarówno w Polsce, jak i na świecie termin „bankowość prywatna” został spopularyzowany, dlatego używany jest zamiennie w niniejszym opracowaniu.

Private banking często utożsamiany jest również z pojęciem wealth management ${ }^{9}$. Obydwa pojęcia interpretowane są wyraźnie niejednoznacznie, choć często używane zamiennie, co rodzi wiele wątpliwości, wynikających przede wszystkim z różnic pomiędzy ich zakresami. Głównym powodem, dla którego nie powinno się utożsamiać private banking z pojęciem wealth management jest fakt, że na rynku obsługi finansowej klienta zamożnego obecnych jest wiele instytucji niebędących bankami. Co więcej, określenie wealth management nie musi się ograniczać wyłącznie do grupy klientów będących osobami fizycznymi, ponieważ może dotyczyć też osób prawnych.

Pojęcie private banking jest pojęciem starszym i jednocześnie wskazuje na bankowy rodowód koncepcji finansowej obsługi zamożnych klientów indywidualnych. Wealth management zwraca bardziej uwagę na współczesny charakter koncepcji, w której oferta stanowi niewielką część, a klientowi proponowane sa produkty i usługi daleko wykraczające poza te ściśle bankowe. Według Dziawgo pojęcie wealth management akcentuje kompleksowość ujęcia kwestii zarządzania majątkiem i jest najbardziej zaawansowana formą planowania finansowego, zapewniającego klientom i ich rodzinom dostęp do wielu wyspecjalizowanych usług związanych z ich majątkiem, przy zwróceniu uwagi również na aktywa niefinansowe. W wealth management wypracowany zysk ma stanowić zabezpieczenie przyszłych pokoleń, dlatego oprócz doradztwa w zakresie optymalizacji podatkowej, inwestycji na rynku nieruchomości czy sukcesji majątku zapewnia nieszablonowe rozwiąania inwestycyjne, jakimi są inwestycje alternatywne ( $\mathrm{w}$ metale szlachetne, kolekcje numizmatyczne,

\footnotetext{
${ }^{9}$ Polskie tłumaczenie: „zarządzanie majątkiem”.
} 
wino, sztukę czy kapitał ludzki). Wealth management stanowią również usługi pomagajace $\mathrm{w}$ zarządzaniu życiem osobistym klienta, tj. family office, usługi typu consierge, różnorodne świadczenia na życzenie, pakiety ubezpieczeniowe oraz wyselekcjonowane niepubliczne oferty inwestycyjne. Takie ujęcie sugeruje bardziej zaawansowana formę wealth management aniżeli private banking. Mimo to instytucje bankowe łączą często funkcjonalnie i osobowo obsługe wealth management $\mathrm{z}$ departamentami private banking, biorac pod uwagę aspekty marketingowe oraz rosnący trend popularności poszczególnych terminów w krajach rozwiniętych, dlatego w zestawieniach statystycznych, raportach czy rankingach instytucji finansowych pojęcia te sa ze sobą często utożsamiane.

\section{CELE I OGÓLNA KLASYFIKACJA PRIVATE BANKING}

$\mathrm{W}$ ramach private banking osiagane sa dwa główne cele: zabezpieczenie aktywów oraz zachowanie lub też zwiększenie realnej ich wartości. Oba cele można osiagnaćc jedynie przez zarządzanie aktywami finansowymi. Zabezpieczenie aktywów ma ochronić je przed zdarzeniami (o charakterze politycznym, gospodarczym, kryminalnym, czy też niekompetencji pracowników), które mogłyby prowadzić do utraty części lub całości ich wartości. Zachowanie aktywów lub zwiększenie ich realnej wartości są celami, których osiagnięcie można uzyskać wyłącznie po uprzedniej realizacji pierwszego.

W przeszłości klientom wystarczało tylko zabezpieczenie wartości aktywów. Przed współczesnym private banking stoi wyzwanie osiagnięcia drugiego celu z możliwą optymalizacja, dotyczącą maksymalizacji zysku przy minimalizacji ryzyka. Cel ten może być osiagany w różnym stopniu i to właśnie stanowi główny przedmiot rywalizacji współczesnego rynku private banking ${ }^{10}$.

Kompleksowe podejście przy określaniu szans i zagrożeń na pomnożenie majątku oraz ryzyka związanego z jego obecną strukturą bierze pod uwagę aktywa płynne, nieruchomości, udziały w spółkach, a także zobowiązania i wszelkie koszty. Klient w zakresie alokacji aktywów ma wybór pomiędzy doradztwem inwestycyjnym ${ }^{11}$ lub oddaniem aktywów w zarządzanie (wybór spośród gotowych, aktywnie zarządzanych portfeli ${ }^{12}$. Konstruowanie indywidualnej oferty poprzedzone jest badaniem akceptowanego poziomu ryzyka, identyfikacji potrzeb i przyszłych celów oraz ich struktury czasowej. Docelowy portfel tworzony jest z zastosowaniem fundamentalnych zasad strategicznej i taktycznej alokacji aktywów, tj. dywersyfikacji aktywów pomiędzy różne klasy, branże, czy regiony, a także aktywnej weryfikacji obranej strategii inwe-

10 L. Dziawgo, Private banking. Bankowość..., s. 20-40.

11 Po podpisaniu odpowiedniej umowy o doradztwo - bank przekazuje klientowi na podstawie aktualnego profilu ryzyka klienta rekomendacje inwestycyjne, na podstawie których klient podejmuje decyzje dotyczące wyboru produktów inwestycyjnych.

${ }^{12}$ Klient nie ma wpływu na skład portfela - wybiera tylko poziom ryzyka i rodzaj strategii. 
stycyjnej, w zależności od sytuacji rynkowej i przy wykluczeniu zmian alokacyjnych pomiędzy jego składnikami o podłożu spekulacyjnym ${ }^{13}$.

Sama klasyfikacja private banking może odbywać się ze względu na klienta, instytucję, ofertę oraz rynek. Bank może bowiem specjalizować się w obsłudze najzamożniejszych z zamożnych klientów lub pochodzących z danego regionu, lub też zorientowanych na określone produkty i usługi. Inną klasyfikacją jest podział ze względu na rodzaj instytucji oferującej private banking, np. bank uniwersalny, inwestycyjny lub też wyspecjalizowany w obsłudze segmentu private. Instytucje oferujące obsługę zamożnych klientów można natomiast podzielić na krajowe, regionalne i globalne. Jeśli kryterium stanowi sama oferta, podział dotyczyć będzie cech i zakresu produktów i usług oraz wpływać na ilość propozycji produktowych, ich jakość oraz rodzaj i stopień specjalizacji całej oferty.

Oferta private banking ma charakter kompleksowy i obejmuje większą lub mniejszą liczbę produktów i usług. Wersja podstawowa jest powszechnie dostępna dla grupy zamożnych klientów i zawiera produkty oraz usługi dostępne w większości banków oferujących private banking. Najzamożniejsi klienci korzystają z oferty w pełnym zakresie, a ofertę tę często nazywa się klasycznym private banking. Natomiast pozostali klienci zamożni, ale nie najzamożniejsi, nadal liczni i ważni dla banków, otrzymują ofertę nieco okrojona, potocznie nazywaną masowym private banking. Oferta specjalistyczna kierowana jest do klientów z najwyższymi saldami i zawiera produkty i usługi spotykane rzadziej na rynku, typu art banking czy wine banking, co wskazuje na częste $\mathrm{w}$ bankach uniwersalnych połączenie jej z ofertą wealth management ${ }^{14}$.

\section{PRIVATE BANKING I WEALTH MANAGEMENT NA ŚWIECIE}

Obsługa osób zamożnych stanowi jedną z najstarszych specjalizacji bankowych. Bankowość określana współcześnie jako private banking rozwijała się już przed kilkuset laty w Szwajcarii, Włoszech czy Anglii. Faza rozwoju segmentu usług private banking \& wealth management na świecie datowana jest na lata dziewięćdziesiąte XX w. Decydujacym momentem dla rozwoju niniejszych usług była fuzja bankowości inwestycyjnej i uniwersalnej (na podstawie uchylenia aktu Glassa-Steagalla z 1933 r.), która umożliwiła rozwój kompleksowych usług finansowych w ramach integracji instytucji finansowych o różnym profilu działalności. Uchylenie tego aktu miało znaczny wpływ na rozwój światowego kryzysu finansowego, przed którego nadejściem rynek usług ścisłej bankowości prywatnej przeżywał intensywny rozwój dyktowany przez dynamikę ekspansji przede wszystkim szwajcarskich i amerykańskich instytucji, takich jak: UBS, Citibank, Merrill Lynch czy Credit Suisse ${ }^{15}$.

\footnotetext{
${ }^{13}$ Zob. http://privatebanking.pb.pl/3860548,97097,zarzadzanie-majatkiem-jest-sztuka.

${ }^{14}$ L. Dziawgo, Private banking. Bankowość..., s. 22-40.

15 Zob. http://privatebanking.warszawa.pl/?m=20150225.
} 
Przez długi czas obsługa zamożnych klientów indywidualnych była bardzo wąską specjalizacją ograniczoną ze względu na niewielki zbiór produktów i usług (w większości bankowych) skierowanych do równie nielicznej, wyselekcjonowanej grupy klientów. Globalne przemiany polityczne, społeczne, gospodarcze i technologiczne wpłynęły na tempo rozwoju tego segmentu bankowości. W ostatnich dziesięcioleciach powstały nieznane dotychczas nowe rynki finansowe, a zakres oferty rozszerzył się znacząco w odpowiedzi na wzrost oczekiwań klientów. Pojawił się wyraźnie zauważalny popyt na profesjonalna obsługę bankowa, adekwatną do wielkości zgromadzonych przez klientów zasobów finansowych.

Początkowo na rynku światowym bankowości prywatnej funkcjonowały wyłącznie banki specjalistyczne. Atrakcyjność, szybki rozwój tego segmentu i związane z tym możliwości zwiększenia przychodów i zysku oraz dywersyfikacji działalności przyciagnęły w kolejnych latach do grona oferentów również banki uniwersalne oraz liczne pozabankowe instytucje finansowe ${ }^{16}$.

Dynamiczny rozwój sektora przyczynił się również do dalszego rozwoju obszarów działalności banków, zaczynając od doradztwa inwestycyjnego $\mathrm{w}$ ramach private banking, poprzez zarządzenie aktywami ${ }^{17}$, wealth management, na kompleksowym zarządzaniu majątkiem rodzinnym ${ }^{18}$ oraz sprawami osobistymi ${ }^{19}$ kończąc. W ofercie dla najzamożniejszych klientów znajdują się klasyczne inwestycje kapitałowe, produkty strukturyzowane oraz wyspecjalizowane instrumenty pochodne. $\mathrm{W}$ spektrum niefinansowych inwestycji alternatywnych podstawową ofertą jest możliwość zakupu dzieł sztuki ${ }^{20}$, metali szlachetnych, a nawet winnic ${ }^{21}$.

$\mathrm{W}$ ujęciu globalnym do potentatów w tej branży należą duże międzynarodowe banki o ugruntowanej pozycji na rynku, posiadające odpowiednio rozwiniętą infrastrukturę organizacyjna, doświadczenie i personel, które pozwalają im na ekspansję działalności, a także definiowanie nowych trendów w tej dziedzinie bankowości. Głównymi przedstawicielami mającymi strategiczne znaczenie dla rynku private banking i wealth management na świecie są Szwajcaria, USA, Wielka Brytania i Niemcy. Szwajcarskie banki dzięki wypracowanemu międzynarodowemu prestiżowi i długoletniej tradycji od lat wyznaczają wzorce dla bankowości prywatnej. Niemniej jednak w ostatnim okresie rolę globalnego lidera przejmuje Bank of America, którego aktywa w zarządzaniu przekroczyły 1,7 biliona USD. Na kolejnych miejscach znalazły się UBS i Morgan Stanley, nieznacznie ustępując pierwszeństwa liderowi ${ }^{22}$.

Poziom zamożności jest jednym z głównych kryteriów segmentacji w private banking i wealth management. Klasyfikacja według wartości posiadanych

\footnotetext{
${ }^{16}$ L. Dziawgo, Private banking. Bankowość..., s. 45-54.

$17 \mathrm{Z}$ ang. assets management.

$18 \mathrm{Z}$ ang. family office.

${ }_{19} \mathrm{Z}$ ang. concierge.

${ }_{20} \mathrm{Z}$ ang. art banking.

${ }^{21} \mathrm{Z}$ ang. wine banking.

22 Zob. http://privatebanking.warszawa.pl/?m=20150225.
} 
aktywów finansowych to jeden z najbardziej oczywistych i stosowanych podziałów. Podejmowane są działania standaryzujące, by umownemu kryterium zamożności przypisać pewne bezwzględne wartości w skali globalnej. Jednym $\mathrm{z}$ takich prób standaryzacji jest operowanie pojęciem high-net-worth individuals (HNWI). Określenie to dotyczy najzamożniejszej grupy klientów ${ }^{23}$.

Według światowych standardów do tej kategorii zaliczyć należy osoby dysponujące co najmniej $1 \mathrm{mln} \mathrm{USD}^{24}$ wolnych aktywów finansowych. Z uwagi na wewnętrzne zróżnicowanie owej grupy klientów instytucje zwykle tworza $\mathrm{w}$ jej obrębie systemy podzbiorów. Jedną $\mathrm{z}$ form tego rodzaju segmentacji jest wyróżnienie według Pricewaterhouse Coopers pięciu podgrup:

1) podgrupy U-HNWI - ultra-high-net-worth individuals - czyli klientów dysponujących aktywami finansowymi w wysokości powyżej $50 \mathrm{mln}$ USD,

2) very high-net-worth individuals - klientów posiadajacych 5-50 mln USD,

3) high-net-worth individuals - klientów posiadajacych 1-5 mln USD,

4) wealthy - posiadajacych od 500 tys. do $1 \mathrm{mln}$ USD,

5) affluent - dysponujących kwota od 100 do 500 tys. USD.

Pewną odmianą powyższej klasyfikacji jest podział klientów private banking na old money (old rich) oraz nouveaux riches (new rich). Pierwsza z tych grup obejmuje klientów pochodzących z zamożnych rodzin, którzy są klientami bankowości prywatnej od pokoleń, natomiast druga - klientów, którzy swój majątek budowali i pomnażali od podstaw i stosunkowo niedawno osiagnęli wysoki status materialny ${ }^{25}$.

Według Światowego Raportu Zamożności 2015 opublikowanego przez Capgemini oraz RBC Wealth Management obszarami o największej populacji najbogatszych ludzi świata są nadal Ameryka Północna oraz region Azji i Pacyfiku. W 2014 r. na świecie pojawił się blisko milion (920 000) nowych milionerów. Liczba najzamożniejszych obywateli świata (HNWI) wzrosła do 14,6 mln, a ich majątki osiagnęły poziom 56,4 bilionów USD, co stanowi wzrost o ok. 7\%, czyli mniej więcej połowę poziomu wzrostu z roku ubiegłego. Według raportu zdecydowana większość najzamożniejszych obywateli świata stosunkowo równomiernie rozproszona jest po Ameryce Północnej, Europie i krajach Azji i Pacyfiku, przy czym ten ostatni region odnotował największy przyrost liczby HNWI i w efekcie mieszka w nim obecnie najwięcej najbogatszych osób na świecie. Na poziomie pojedynczych państw ponad połowa (52\%) wzrostu liczby HNWI na świecie przypada na Chiny i Stany Zjednoczone. Jeśli chodzi o poziom przyrostu populacji najzamożniejszych obywateli (26\%) oraz ich majątku (28\%), światowym liderem okazały się Indie.

${ }^{23}$ Zob. http://wneiz.pl/nauka_wneiz/frfu/64-2013/FRFU-64-t1-513.pdf.

${ }^{24}$ Usługa wealth management za granica, za grupę docelową przyjmuje osoby, które powierzają instytucji aktywa finansowe w wysokości co najmniej $1 \mathrm{mln}$ USD. Wysokość bariery finansowej uzależniona jest od obszaru działania oraz rodzaju podmiotu oferującego usługę.

${ }^{25}$ Raport PricewaterhouseCoopers Global Private Banking/Wealth Management Survey 2007: Executive Summary, http://www.pwc.com/extweb/pwcpublications.nsf/docid/ A4B9D41B1898E153852571E7006DA6D9 [dostęp: 4.01.2009]. 
Majątek najzamożniejszych obywateli świata ma do 2017 r. osiagnać poziom 70 bilionów USD. Prognozy wskazuja, że ogólnoświatowy poziom majątku w rękach HNWI będzie wzrastał o niemal 8\% rocznie od końca 2014 do 2017 r., osiagając 70,5 biliona USD, przy czym liderem wzrostu będzie tu region Azji i Pacyfiku, przy coraz silniejszym udziale Europy ${ }^{26}$.

\section{DETERMINANTY KSZTAETUJĄCE PRIVATE BANKING W POLSCE}

Społeczeństwo polskie bogaci się w dość szybkim tempie. Z roku na rok powiększa się grupa zamożnych obywateli, od lat zwiększają się także ich łączne dochody netto. Jak wynika z Raportu KPMG dotyczqcego rynku dóbr luksusowych w Polsce ${ }^{27}$, liczba osób zamożnych (tj. osiagających dochód miesięczny powyżej 7,1 tys. zł brutto) systematycznie wzrasta. W 2011 r. grupa osób zamożnych w Polsce (zarabiających ponad 85 tys. zł rocznie) stanowiła około 550 tys. osób. Raport podaje, że do końca 2014 r. liczebność tej grupy wzrosła do 878 tys. (wzrost o 6\% w ujęciu do 2013 r. - w którym liczba ta wynosiła 832 tys. osób), natomiast ich łączny dochód - do 141 mld zł (co oznacza wzrost o 5\% w ujęciu do 2013 r., w którym dochód łączny wynosił 134 mld zł). Należy oczekiwać, że rosnacy trend utrzyma się w przyszłości. Według szacunków KPMG w 2016 r. liczba zamożnych i bogatych podatników może po raz pierwszy przekroczyć milion osób, a w 2017 r. ich łączne dochody moga osiagnąć wartość około $200 \mathrm{mld} \mathrm{z}^{28}$.

Mimo że osób z płynnymi aktywami (gotówka, akcje, obligacje, lokaty bankowe), przekraczajacymi $1 \mathrm{mln}$ zł (co zazwyczaj stanowi próg, od którego można zaczać korzystać z pełnego spektrum usług private banking w Polsce), jest wciąż wyraźnie mniej niż w nawet kilkukrotnie mniejszych pod względem ludności krajach „starej Europy”, nie ulega wątpliwości, że liczba ta z roku na rok będzie wzrastać, zwłaszcza że z każdym kolejnym pokoleniem przybywa w Polsce osób, które po raz pierwszy po okresie transformacji odziedzicza majątki. W 2014 r. mieszkało w Polsce 47 tys. osób HNWI, tj. posiadających aktywa płynne o wartości co najmniej $1 \mathrm{mln}$ USD. Godnym uwagi jest fakt, że osoby te swój stan posiadania najczęściej zawdzięczają sobie, w przeciwieństwie do dobrze sytuowanych osób z Europy Zachodniej, gdzie często jest to kwestia dziedziczenia majątku ${ }^{29}$.

${ }^{26}$ Zob. https://www.pl.capgemini.com/aktualnosci/rekordowa-liczba-i-majatki-najzamozniejszychobywateli-swiata-hnwi.

${ }^{27}$ Raport KPMG w Polsce „Rynek dóbr luksusowych w Polsce”, Edycja 2014, http://www. kpmg.com/PL/pl/IssuesAndInsights/ArticlesPublications/Strony/Informacja-prasowa-Rynekdobr-luksusowych-w-Polsce-Edycja-2014.aspx.

${ }_{28}$ Zob. http://wgospodarce.pl/informacje/18031-enklawa-dostatku-w-polsce-jest-878-tys-osobzamoznych-i-bogatych-w-ciagu-roku-przybedzie-ich-ok-60-tys.

${ }_{29}$ Zob. http://privatebanking.pb.pl/3860554,18257,pozadane-uslugi-dla-bogatszych. 


\section{Tabela 1}

Liczba osób zamożnych i bogatych w Polsce (w tys.) oraz ich roczny dochód do dyspozycji (w mld zł)

\begin{tabular}{|l|l|c|c|c|c|c|c|c|c|c|}
\cline { 2 - 9 } \multicolumn{1}{l|}{} & 2008 & 2009 & 2010 & 2011 & 2012 & 2013 & $2014(\mathrm{p})$ & 2015 (p) & 2016 (p) & 2017 (p) \\
\hline $\begin{array}{l}\text { Podatnicy } \\
\text { rozliczajacy się } \\
\text { według skali } \\
\text { podatkowej (drugi } \\
\text { przedział - roczny } \\
\text { dochód powyżej } \\
85 \text { tys. zł brutto) }\end{array}$ & 342 & 387 & 464 & 522 & 554 & 602 & 642 & 698 & 775 & 868 \\
\hline $\begin{array}{l}\text { Podatnicy } \\
\text { osiagający } \\
\text { dochód powyżej } \\
85 \text { tys. rocznie, } \\
\text { rozliczający się } \\
\text { według podatku } \\
\text { liniowego 19\% }\end{array}$ & 232 & 191 & 197 & 214 & 214 & 230 & 236 & 250 & 265 & 285 \\
\hline $\begin{array}{l}\text { Roczny dochód } \\
\text { osób zamożnych } \\
\text { i bogatych razem }\end{array}$ & 98,5 & 101,6 & 110,6 & 122,5 & 126,9 & 133,6 & 140,8 & 153,8 & 174,2 & 200,5 \\
\hline
\end{tabular}

(p) prognoza

Źródło: opracowanie własne na podstawie Raport KPMG w Polsce „Rynek dóbr luksusowych w Polsce” $z 2014^{30}$.

Kluczową rolę w rozwoju światowej gospodarki zaczyna odgrywać grupa osób budujących nowe majątki, stanowiąca najszybciej rosnący segment osób zamożnych na świecie. Z raportu opracowanego w 2015 r. przez Economist Intelligence Unit (EIU) na zlecenie Citibanku wynika, że Polska znajduje się w pierwszej dziesiątce ${ }^{31}$ krajów z perspektywą najwyższego wzrostu liczby gospodarstw domowych, których majątek wyceniany jest na min. 400 tys. zł ${ }^{32}$. Szacuje się, że aktualnie gospodarstw tzw. budujących nowe majątki w Polsce ${ }^{33}$ jest ponad 700 tys. (w ciagu 5 lat liczba takich gospodarstw ma sięgnąc ponad $2 \mathrm{mln}$ ), a potencjał zwiększenia liczebności tej grupy osób w Polsce jest znacznie wyższy niż w krajach rozwiniętych (m.in. Niemcy, Francja czy Włochy). Jak wynika z Raportu -8 na 10 osób budujących swój majątek zgromadziło go w ciagu 10 ostatnich lat, a mniej niż $3 \%$ z nich twierdzi, że odziedziczyło go lub dostało w jakikolwiek sposób. Grupę tę stanowia przede wszystkim osoby świadome odpowiedzialności społecznej, które swój kapitał zgromadziły dzięki własnej pracy i odpowiedniemu wykorzystaniu dobrej strony globalizacji. $\mathrm{Na}$ przestrzeni kolejnej dekady segment ten rosnąc będzie znacznie szybciej od

${ }^{30}$ Zob. http://www.kpmg.com/PL/pl/IssuesAndInsights/ArticlesPublications/Strony/Informacjaprasowa-Rynek-dobr-luksusowych-w-Polsce-Edycja-2014.aspx.

${ }^{31}$ Wynika z pomiarów trendów wzrostu przeprowadzonych w 32 krajach na świecie.

32 Grupa ta dysponuje globalnie aktywami wynoszącymi łącznie 88 bilionów USD, a prognozy wskazuja, że co roku ich wartość będzie rosnąć średnio o 7\% - tj. do 145 bilionów USD w 2020 r.

${ }^{33}$ Budujaccy nowe majątki to grupa o majątkach wycenianych od 400 tys. do $8 \mathrm{mln} \mathrm{zł}$. 
pozostałych segmentów zamożnych klientów, wpływając tym samym silnie na dalszy rozwój segmentu klientów bardzo zamożnych ${ }^{34}$.

Polska bankowość prywatna próbuje czerpać wzory z zachodnich instytucji, a efekt naśladownictwa wpływa pozytywnie na ciagły rozwój oferty dostępnej w polskich instytucjach finansowych. Strategie banków w obszarze private banking zmieniają się w odpowiedzi na sytuację geopolityczna, społeczną i finansową panujaccą na rynkach światowych. Globalizacja rynku i coraz większy dostęp do oferty usług globalnych powoduja, że polscy klienci private banking coraz chętniej korzystają z usług oferowanych przez rodzime instytucje finansowe. Podobne znaczenie ma powiąanie finansów osobistych z firmowymi, wymuszające poniekąd potrzebę funkcjonowania w krajowym systemie prawnym i wykorzystywanie rozwiązań finansowych optymalizujacych zyski z inwestycji.

Pomimo że rynek private banking w Polsce zmienił znacząco swoje oblicze $\mathrm{w}$ ciagu ostatnich lat, to jednak nie można go w pełni porównywać z rozwiniętymi rynkami europejskimi czy też z rynkiem amerykańskim. Głównym ograniczeniem jest zamożność polskiego społeczeństwa. Private banking dostosowany do polskich warunków zmienił nieco elitarny charakter tego segmentu znany z wzorca zachodniego. W Polsce progi wejścia do private banking dostosowane są do naszych realiów, a tym samym dużo niższe niż na Zachodzie. W kręgu zainteresowania polskich banków uniwersalnych znalazł się „masowy” segment klientów zamożnych, dysponujący aktywami płynnymi na poziomie pomiędzy 100 a 500 tys. euro. Usługi private banking adresowane sa do dużo liczniejszej grupy klientów aniżeli na Zachodzie. Tak duża rozbieżność $\mathrm{w}$ kryterium dostępu do oferty private banking pomiędzy krajami rozwiniętymi a rozwijającymi się wynika z faktu, że w Europie Środkowej i Wschodniej nie wykształciła się jeszcze warstwa społeczna opierająca swoją zamożność na bogactwie akumulowanym i dziedziczonym przez dziesiątki lat. Pomimo specyficznej struktury bogactwa w Polsce rynek bankowości prywatnej będzie rozwijał się równolegle z rozwojem bazy demograficznej klientów i zbliżał się powoli do wersji zachodniej.

Wymagania zamożnych klientów indywidualnych są również powodem stałego rozwoju bankowości prywatnej i bez wątpienia stanowią inspirację dla wprowadzania coraz to nowszych produktów i usług z zakresu działalności bankowej czy finansowej. Szeroki zakres obsługi stymulowany jest również przez sam bank, którego celem jest zwiększenie efektywności współpracy z klientem, a tym samym podniesienie własnych wyników bilansowych. Rosnaca liczba podmiotów obsługujących zamożnych klientów wzmacnia u klientów chęć dywersyfikacji ryzyka portfela i powoduje, że rozdzielają oni swoje aktywa pomiędzy coraz większą liczbę instytucji finansowych. Wzrost konkurencyjności jest jednym z aktualnych wyzwań stojących przed współczesnym private banking, wpływającym na ciagły rozwój oferty, której coraz szerszy zakres powoduje, że produkty i usługi o charakterze standardowym i tradycyjnym stanowią zaledwie niewielką część oferty współczesnego private banking ${ }^{35}$.

${ }^{34}$ Zob. http://privatebanking.pb.pl/3860554,18257,pozadane-uslugi-dla-bogatszych.

35 L. Dziawgo, Private banking. Bankowość..., s. 22-40. 
Banki, jako instytucje świadczące usługi dla zamożnych klientów, ewoluuja $\mathrm{z}$ tego powodu w ujęciu funkcjonalnym od pasywnej roli realizatora zleceń transakcyjnych do aktywnej roli zarządcy majątku klienta i właśnie w tym zakresie aktywności konkuruja pomiędzy sobą przez ciagle rozwijane spektrum specjalistycznych usług bankowych, finansowych i pozafinansowych. Jest to konsekwencja dążenia banków do jednoczesnego pełnienia wielu funkcji wobec klienta i kompleksowego zaspokajania jego oczekiwań, nie tylko w zakresie gromadzenia, zabezpieczania i pomnażania majątku, ale także wielu innych potrzeb nie tylko finansowych. Priorytetowe stają się działania zapewniające budowanie i utrzymywanie z klientami długoterminowych relacji przechodzacych z pokolenia na pokolenie. Trend ten determinuje również demografia zamożna część pokolenia wyżu demograficznego w Polsce osiaga właśnie wiek emerytalny, skupiając się tym samym na możliwościach transferu majątku młodszym pokoleniom. $\mathrm{Z}$ tego powodu instytucje finansowe musza wypracować długoterminowe rozwiązania, a początkująca współpraca z młodszym pokoleniem stawia z kolei przed bankami świadczacymi usługi private banking wyzwanie i konieczność wykorzystania najnowszych rozwiązań mobilnych ${ }^{36}$.

\section{NAJWAŻNIEJSI OFERENCI USŁUG BANKOWOŚCI PRYWATNEJ NA POLSKIM RYNKU}

Polska bankowość prywatna narodziła się za sprawą wyodrębnienia z bankowości korporacyjnej jednostek kierujących usługi do zamożnych osób prywatnych. Bank Handlowy w 1993 r. udostępnił jako pierwszy tego typu usługę dla klientów indywidualnych. W 1995 r. mBank (jako BRE Private Banking) zaczął oferować taką usługę. Trzy lata później do konkurencji dołączył Bank Pekao S.A. i kolejno dalsze banki krajowe i filie banków zagranicznych. Pierwszym bankiem, który skierował swoją ofertą wyłącznie do klientów zamożnych, był Noble Bank S.A. (po fuzji działający na rynku pod nazwą Getin Noble Bank) $)^{37}$.

Powstanie oferty wealth management $\mathrm{w}$ Polsce datuje się na 2003 r., kiedy to szwajcarski UBS (bez działalności operacyjnej w Polsce) wprowadził ofertę tych usług w formie off-shore, obsługując pozyskanych klientów transakcyjnie w Zurychu.

Pionierem i liderem w świadczeniu usług wealth management na polskim rynku jest mBank Wealth Management (dawniej BRE Wealth Management), który rozpoczą swoją działalność na początku 2007 r. Zwiększająca się konkurencja w znacznym stopniu pozwala na optymalizację i wzrost efektywności zarządzania majątkiem osób zamożnych. Obecnie na rynku oprócz UBS i BRE pojawiaja się konkurencyjne instytucje tego rodzaju, np. przedstawicielstwo luksemburskiego banku Banque Privée Edmond de Rothschild Europe czy austriackiego Sal, Oppenheim, Sarasin Bank czy KBL Private Bankers. Taka

${ }^{36}$ Zob. http://zif.wzr.pl/pim/2013_2_1_53.pdf.

${ }^{37}$ Zob. http://www.bankier.pl/wiadomosc/Bankowosc-dla-bogaczy-2854648.html. 
sytuacja daje możliwość zbudowania nowej grupy najważniejszych i najsilniejszych graczy na rynku usług bankowości prywatnej, przebudowę organizacyjna i operacyjna instytucji wealth management, a także traktowanie najbogatszych klientów z większą rozwagą i zaangażowaniem, ponieważ wysoki poziom jakości i zadowolenie obsługi to główne powody przywiązania klienta do instytucji ${ }^{38}$.

Ekspansja tego rodzaju usług spowodowała, że dziś wszystkie liczące się banki posiadają w swojej ofercie usługę zarządzania aktywami osób zamożnych. Obecnie private banking to nie tylko luksusowo wyposażone placówki, dyskrecja i indywidualny doradca, ale przede wszystkim szeroka oferta, elastyczność i jakość proponowanych rozwiązań. Głównym filarem bankowości prywatnej stało się doradztwo inwestycyjne oraz kompleksowe zarządzanie majątkiem, zarówno aktywami finansowymi, jak też pozafinansowymi, a także elastyczność proponowanych rozwiązań. Mimo że kryteria dostępu do tego rodzaju usług dostosowane sa do poziomu zamożności polskiego społeczeństwa, dostęp do tej usługi, podobnie jak za granica, warunkowany jest wielkością posiadanych aktywów i/lub miesięcznych wpływów na rachunek klienta ${ }^{39}$.

Kapitałowe kryterium dostępu do podstawowych usług typu private banking na przykładach z rynku polskiego przedstawia tabela 2 .

W niniejszej grupie zaledwie kilka banków zawiera w wachlarzu swoich usług ofertę typu wealth management. BRE Bank (aktualnie mBank) jako jedyny wyraźnie oddzielił usługi private banking od wealth management, udostępniając tę usługę klientom z kapitałem minimalnym na poziomie $2 \mathrm{mln}$ zł. Getin Noble Bank, Bank Millenium i Deutsche Bank traktuja wealth management jako dodatkowy element oferty private banking, natomiast Citi Handlowy oferuje ja przez ofertę Citi Private Bank.

W polskiej bankowości prywatnej najczęstszym kryterium kapitałowym jest dysponowanie kapitałem w wysokości 500 tys. lub $1 \mathrm{mln}$ zł. Oznacza to, że przy segmentacji klienta ze względu na stan posiadanych płynnych aktywów powierzonych bankowi polscy klienci private banking $\mathrm{w}$ rozwiniętych gospodarczo krajach (gdzie bariera przynależności do grona klientów bankowości prywatnej wiąże się z koniecznością posiadania równowartości $1 \mathrm{mln}$ USD) zostaliby w dużej mierze zaliczeni do niższej warstwy piramidy, tj. do grupy zamożnych ${ }^{40} \mathrm{z}$ aktywami od 100 do 500 tys. USD.

$\mathrm{W}$ praktyce oznacza to, że polska wersja private banking nie jest de facto kierowana do HNWI, tj. osób dysponujących płynnymi aktywami co najmniej na poziomie $1 \mathrm{mln}$ USD. Mimo że w Polsce gama produktów oferowanych klientom sektora bankowości prywatnej poszerza się z roku na rok, to oferta ta nadal pozostaje poza standardami ofert banków działających w obszarze krajów rozwiniętych, a wspomniana różnica warunkowana jest w dużej mierze wysokością wnoszonego kapitału ${ }^{41}$.

${ }^{38}$ Zob. http://privatebanking.warszawa.pl/?m=20150225.

${ }^{39}$ Zob. http://www.bankier.pl/wiadomosc/Bankowosc-dla-bogaczy-2854648.html.

${ }^{40}$ Zob. ang. affluent, określany także jako sub-HNWI.

${ }^{41}$ Zob. http://www.privatebanking.pl/index.php?option=com_content\&task=view\&id=670\&It emid $=28$. 
Tabela 2

Poziom aktywów pozwalający korzystać z oferty private banking w poszczególnych bankach w Polsce

\begin{tabular}{|c|c|}
\hline Nazwa Banku & Kryteria dostępu do bankowości prywatnej \\
\hline $\begin{array}{l}\text { mBank Private Banking } \\
\text { (BRE Bank) }\end{array}$ & $\begin{array}{l}\text { - } 1 \text { mln zł lub równowartości tej kwoty w walutach obcych } \\
\text { - usługi wealth management dostępne są od } 2 \text { mln zł }\end{array}$ \\
\hline $\begin{array}{l}\text { Deutsche Bank Polska S.A. } \\
\text { Elite Private Banking }\end{array}$ & $\begin{array}{l}\text { - min. } 500 \text { tys. zł (lub równowartość) aktywów ulokowanych } \\
\text { w DB lub } \\
\text { - regularne wpływy dochodu min. } 25 \text { tys. zł miesięcznie, lub } \\
\text { - pozycja kredytowa w wysokości } 1,5 \mathrm{mln} \text { zł } \\
\text { - dostęp do produktów typu Club Deal - od kwoty } \\
\text { równowartość } 1 \text { mln euro }\end{array}$ \\
\hline $\begin{array}{l}\text { Noble Bank } \\
\text { Private Banking }\end{array}$ & $\begin{array}{l}\text { - aktywa zgromadzone w banku na poziomie } 500 \text { tys. zł (lub } \\
\text { równowartość) } \\
\text { - usługi wealth management od } 2 \text { mln zł } \\
\text { - dostępność FIZ - przy inwestycji od ok. } 5 \text { mln zł }\end{array}$ \\
\hline $\begin{array}{l}\text { PKO BP } \\
\text { Private Banking }\end{array}$ & $\begin{array}{l}\text { - aktywa w minimalnej wysokości } 1 \text { mln zł na rachunkach } \\
\text { i produktach w Grupie Kapitałowej PKO BP }\end{array}$ \\
\hline $\begin{array}{l}\text { Bank Handlowy } \\
\text { (Citibank) } \\
\text { CitiSelect/Citigold }\end{array}$ & $\begin{array}{l}\text { - średnie miesięczne saldo środków min. } 1,5 \text { mln zł lub } \\
\text { regularne wpływy dochodu na konto min. } 40 \text { tys. zł } \\
\text { miesięcznie (CitiSelect) } \\
\text { - aktywa wysokości min. } 300 \text { tys. zł (Citigold) lub wpływy } \\
\text { miesięczne min. } 15 \text { tys. zł }\end{array}$ \\
\hline $\begin{array}{l}\text { Raiffeisen Polbank } \\
\text { Friedrich Wilhelm } \\
\text { Raiffeisen }\end{array}$ & - aktywa w minimalnej wysokości $1 \mathrm{mln}$ zł \\
\hline $\begin{array}{l}\text { Alior Bank } \\
\text { Private Banking }\end{array}$ & $\begin{array}{l}\text { - aktywa w wysokości co najmniej } 400 \text { tys. zł lub kredyt } \\
\text { powyżej } 1 \text { mln zł }\end{array}$ \\
\hline $\begin{array}{l}\text { ING } \\
\text { Private Banking }\end{array}$ & $\begin{array}{l}\text { - aktywa w wysokości co najmniej } 500 \text { tys. zł (lub } \\
\text { równowartośc) } \\
\text { - wealth management przy aktywach min. } 2 \mathrm{mln} \text { zł (lub } \\
\text { równowartość) }\end{array}$ \\
\hline $\begin{array}{l}\text { PKO S.A. Platinum } \\
\text { Private Banking }\end{array}$ & $\begin{array}{l}\text { - oferta private banking kierowana jest wyłącznie do klientów } \\
\text { posiadających konto Platinum, z wymaganymi aktywami } \\
\text { rzędu równowartości } 1 \mathrm{mln} \text { zł }\end{array}$ \\
\hline $\begin{array}{l}\text { Bank Millennium S.A. } \\
\text { Prestige }\end{array}$ & $\begin{array}{l}\text { - aktywa powyżej } 1 \mathrm{mln} \text { zł } \\
\text { - wersja prestige dla klientów affluent - zaczyna się przy } \\
\text { wpływach w wysokości od } 10 \text { tys. zł miesięcznie lub } \\
\text { zaangażowaniu środków powyżej } 100 \text { tys. zł }\end{array}$ \\
\hline
\end{tabular}

Źródło: opracowanie własne - stan w lipcu 2015 r.

Według ostatniego rankingu ${ }^{42}$ Forbesa oceniającego liderów private banking w Polsce (za rok 2014) kolejne pięć pierwszych miejsc zajmują:

1. Noble Bank,

2. mBank (dawniej BRE Bank),

${ }^{42}$ Zob. http://www.forbes.pl/rating-private-banking-noble-bank-mwealth-i-fwr-liderami-rynku, artykuly, $189034,1,1 . \mathrm{html}$. 
3. Raiffeisen Bank,

4. Deutsche Bank,

5. ING Bank.

Na uwagę zasługuje fakt, że istotą private banking jest indywidualne podejście do klienta, dlatego operowanie widełkami kwotowymi nie stanowi uniwersalnego punktu odniesienia. Niezależnie od wysokości lokowanych środków każdy klient otrzymuje obsługę i konsulting na najwyższym poziomie. Różnica tkwi raczej w wachlarzu usług i elitarnych produktów (oferty niepubliczne czy też subskrypcje zamknięte), które można zarekomendować klientom inwestującym najwyższe kwoty. Indywidualne produkty szyte na miarę (tzw. Club Deal) tworzone są dla osób dysponujacych dużymi kwotami (1 mln euro), w przypadku których oszczędzanie na lokatach czy inwestowanie w fundusze inwestycyjne może okazać się niewystarczające ${ }^{43}$.

Do usług wyróżniających się na polskim rynku bankowości prywatnej zaliczyć możemy inwestycje w produkty będące pochodną rynku nieruchomości (m.in. fundusze, certyfikaty). Trend ten rozpoznał najszybciej Noble Bank, który w 2014 r. nawiązał współpracę z Sotheby's International Realty. Efektem tej współpracy stało się włączenie do oferty bankowości prywatnej Noble Banku możliwości zakupu (również w kategoriach inwestycyjnych) prestiżowych nieruchomości zlokalizowanych na całym świecie. Na razie jest to jedyny bank w Polsce, który usystematyzował tego rodzaju inwestycje ${ }^{44}$.

Specjalnym produktem dla wybranych klientów banków są prestiżowe karty. Większość instytucji finansowych w Polsce oferuje klientom bankowości prywatnej kartę platynowa, przybywa jednak coraz więcej takich, które wprowadzaja karty Visa Infinite, MasterCard World Signia czy World Elite MasterCard. Wśród kart debetowych wyróżnia się Noble Bank z kartą MasterCard Debit Platinum Metal, wykonaną ze stopu srebra i niklu. Jest to pierwsza unikatowa karta tego typu w Polsce, jak również i na całym świecie, co z pewnością czyni ją niezwykle prestiżowym środkiem płatniczym (dostępnym tylko dla klientów Noble Banku).

Jedną z najbardziej ekskluzywnych kart na świecie jest czarna karta Centurion wydawana przez American Express. W Polsce w jej wydawaniu pośredniczy m.in. mBank. Przyszły posiadacz Centuriona musi zostać zaproszony do programu przez centralę główną American Express w Nowym Jorku lub europejską w Londynie (warunek utrzymania karty to obroty roczne na poziomie co najmniej 250 tys. USD) ${ }^{45}$. Na całym świecie użytkownikami czarnej karty jest około 10 tys. osób (w Polsce to zaledwie kilkadziesiąt osób) ${ }^{46}$.

Klienci private banking korzystaja z wielu dodatkowych bonusów, np. dostępnych dla nich programów consierge (program przywilejów) obejmujących szereg usług z zakresu wypoczynku, rozrywki, zakupów, sportu czy motoryzacji. W tej kwestii polski private banking jest spójny z zachodnimi wzorcami.

\footnotetext{
${ }^{43}$ Zob. http://www.bankier.pl/wiadomosc/Bankowosc-dla-bogaczy-2854648.html.

${ }^{44}$ Zob. http://www.forbes.pl/rating-private-banking-noble-bank-mwealth-i-fwr-liderami-rynku, artykuly,189034,1,1.html.

${ }^{45}$ Roczna opłata za używanie Centuriona zależy od kraju. W USA wynosi 2800 USD, a w większości państw Unii Europejskiej - 2800 EUR lub 1800 GBP.

${ }^{46}$ Zob. http://privatebanking.pb.pl/3860558,14628,luksus-nie-dla-kazdego.
} 


\section{PODSUMOWANIE}

Private banking stanowi obecnie znaczącą część współczesnej bankowości, co wynika z potencjału samego rynku, ale również fali narastającego kapitału, który za pośrednictwem private banking pojawia się na rynku finansowym, wpływając tym samym na funkcjonowanie globalnej gospodarki. Nie bez znaczenia pozostaje udział private banking $\mathrm{w}$ procesach akumulacji, transferu i alokacji prywatnych aktywów finansowych w skali globalnej z uwagi na międzynarodowy charakter współczesnego private banking.

Dynamika rozwoju segmentu bankowości prywatnej związana jest ze wzrostem liczby majętnych osób i wartości ich majątków oraz wpływem rosnącego zapotrzebowania na specyficzne, prestiżowe usługi finansowe dla zamożnych klientów. Instytucje finansowe, zdając sobie sprawę z tego faktu, rozwijaja swoje struktury organizacyjne o departamenty private banking, a skala działalności w tym obszarze rośnie zarówno ze względu na liczbę zamożnych klientów banków, jak i zakres oferty i usług do nich skierowanych.

Rynek usług private banking w Polsce opiera się wciąż na trochę innych zasadach i potrzebach niż rynki w Europie Zachodniej. Bolączką polskiej bankowości prywatnej sa zbyt niskie progi wejścia. Oferta zmienia się wolno, ale systematycznie, zgodnie z tempem, w jakim dojrzewa nasz rynek. Kluczowym czynnikiem budowania przewagi konkurencyjnej na rynku usług finansowych dla osób o wysokim statusie finansowym jest jakość świadczonej obsługi, wyrażana umiejętnością nawiązania i utrzymania relacji mających największy wpływ na poziom satysfakcji klienta. Pomimo postępu technologicznego i nieuchronnego przenikania do życia codziennego nowych sposobów i form komunikacji tradycyjna bankowość oparta na kontaktach z kompetentnymi doradcami jest podstawą obsługi w segmencie klientów zamożnych. Klienci od oferty private banking oczekują nie tylko świadczenia usług finansowych, ale globalnej opieki nad powierzonym majątkiem. Wraz ze zmianą oczekiwań i profilu klientów zamożnych zmienia się również oblicze polskiej bankowości prywatnej.

Współczesna jej postać ewoluuje w kierunku modelu polegającego na pogłębianiu relacji z bankiem i potrzebie powierzenia bankierowi coraz szerszego wachlarza spraw nie tylko inwestycyjnych, lecz także doradczych, prawnych czy biznesowych. Można się spodziewać, że istotnymi elementami oferty dla klientów bankowości prywatnej staną się wkrótce: pomoc prawna, optymalizacja podatkowa oraz planowanie przekazania majattku kolejnym pokoleniom (sukcesja). W przypadku przedsiębiorców szukających sposobu na sfinansowanie rozwoju działalności będą to produkty i usługi wspomagające pozyskanie kapitału lub sprzedaż udziałów w spółce.

Mimo uwag dotyczących jakości usług polskiego private banking należy zwrócić uwagę na fakt, że krajowy rynek znajduje się w silnej fazie rozwoju i dysponuje ogromnym potencjałem dalszego wzrostu. Na polskim rynku obecnie niewiele jest instytucji wyspecjalizowanych jedynie w tego rodzaju bankowości, a większość usług tego typu oferowana jest przez departamenty 
uniwersalnych banków komercyjnych. Wraz z wykorzystywaniem potencjału rozwojowego usług bankowości prywatnej polskiego rynku, stopień profesjonalnej obsługi oraz kompleksowego doradztwa będzie ewoluował, podążając za silnymi światowymi wzorcami. W obszarze tym powstaje ogromne pole do zaoferowania wyspecjalizowanych i kompleksowych usług doradczych zamożnym klientom indywidualnym, w tym przede wszystkim zwiększenie sił i nakładów na rozwój tych usług i przywiązywanie dużej wagi do jakości świadczonych usług.

mgr Katarzyna Kupka

Uniwersytet Ekonomiczny w Poznaniu

\section{PRIVATE BANKING - THE CONDITION AND PROSPECTS \\ OF ITS DEVELOPMENT IN POLAND}

\section{Sum mary}

Private banking is the most advanced form of retail banking and constitutes a significant part of a modern banking strategy. It is recognised as one of the currently fastest growing areas of economy.

Polish private banking draws patterns from Western institutions, and the effect of imitation has a positive effect on its shape and further development of the range of services offered. This is owing to the potential of the market, increasing capital and increased expectations of the wealthiest customers. All these have become determinants of its further development. With the use of the development potential of the Polish private banking market, the degree of professional services and comprehensive advice will continue to evolve, following the global pattern. This, in turn, creates enormous possibilities for offering specialised and complex new services on the Polish market, while increasing at the same time the efforts and investment in ascertaining their quality. 
